\title{
Kecenderungan \#DiRumahSaja dan Perilaku Adaptif dalam Melawan Covid-19
}

\author{
The Tendency of \#StayAtHome and Adaptive Behavior in Combating \\ Covid-19
}

\author{
Tabah Aris Nurjaman \\ Program Studi Psikologi, Fakultas Bisnis dan Humaniora, Universitas Teknologi Yogyakarta
}

\author{
Submitted 13 April 2020 Accepted 3 August $2021 \quad$ Published 30 October 2021
}

\begin{abstract}
Covid-19 outbreak has taken many lives to this day, so it requires our awareness to take collective action in any form. This study aimed to explore adaptive behaviors against Covid-19 and to predict the tendency to stay at home based on gender, developmental stage, and psychological domains (cognition, affection, and behavior). The exploration phase of adaptive behavior was conducted by using an indigenous psychological approach. The prediction phase of the \#stayathome tendency was conducted by implementing machine learning with a decision tree model. Data was collected by involving 272 respondents $\left(67.6 \%\right.$ female; $\left.M_{\text {age }}=24.4 ; S D_{\text {age }}=10.38\right)$. Based on the exploration study, the responsibility of Covid-19 outbreak lies in humankind (67.65\%), policymakers $(22.79 \%)$, and other objects $(9.56 \%)$. The emotional response to Covid-19 was dominated by anxiety $(47.79 \%)$, followed by trying to stay calm $(32.72 \%)$ and sadness $(19.47 \%)$. The adaptive behavior was shown by breaking the chain of virus spread $(45.22 \%)$, maintaining a clean and healthy lifestyle $(42.28 \%)$, and following the government's instructions $(12.5 \%)$. Based on the decision tree model, \#stayathome tendency occurred in early and middle adult women who felt anxiety about Covid-19 and behaved adaptively by breaking the chain of virus spread.
\end{abstract}

Keywords: adaptive behavior; Covid-19; decision tree model; indigenous psychology; \#stayathome

Abstrak. Wabah Covid-19 telah merenggut banyak nyawa hingga saat ini, sehingga menuntut kesadaran kita untuk berusaha bersama-sama melakukan tindakan kolektif dalam bentuk apapun. Penelitian ini bertujuan untuk mengeksplorasi perilaku adaptif dalam melawan Covid-19 dan memprediksi kecenderungan untuk berdiam di tempat tinggal atau \#dirumahsaja berdasarkan jenis kelamin, masa perkembangan, dan skema psikologis (kognisi, afeksi, dan perilaku). Tahap eksplorasi perilaku adaptif dilakukan dengan menggunakan pendekatan psikologi indigenous. Tahap prediksi kecenderungan \#dirumahsaja dilakukan dengan implementasi machine learning model decision tree. Pengambilan data dilakukan dalam satu waktu dengan melibatkan 272 responden (67,6\% wanita; $\mathrm{M}_{\text {usia }}=24,4 ; \mathrm{SD}_{\text {usia }}=10,38$ ). Berdasarkan hasil eksplorasi, penyebaran Covid-19 menjadi tanggung jawab diri sendiri $(67,65 \%)$, pemangku kebijakan $(22,79 \%)$, dan objek lain (9,56\%). Kondisi afeksi dalam menyikapi Covid-19 didominasi oleh perasaan cemas (47,79\%), diikuti usaha tetap tenang $(32,72 \%)$ dan perasaan sedih $(19,47 \%)$. Perilaku adaptif ditunjukkan dengan memutus rantai penyebaran virus $(45,22 \%)$, menjaga pola hidup bersih dan sehat (42,28\%), dan mengikuti anjuran pemerintah $(12,5 \%)$. Berdasarkan model decision tree, kecenderungan \#dirumahsaja terjadi pada wanita dewasa awal dan dewasa madya yang merasa cemas akan Covid-19 dan berperilaku adaptif dengan memutus rantai penyebaran virus.

Kata kunci: Covid-19; decision tree model; \#dirumahsaja; perilaku adaptif; psikologi indigenous 
Penyakit akibat virus Corona (Coronavirus Disease 2019; Covid-19) telah merenggut nyawa banyak orang di dunia. Berdasarkan laporan Gugus Tugas Percepatan Penanganan Covid-19 (2020, 11 April) di laman resminya hingga saat penulisan ini tercatat 92.941 kematian dari 1.528.161 kasus terkonfirmasi yang tersebar di 213 negara; dan 327 meninggal dari 3.842 kasus terkonfirmasi di Indonesia. Angka korban meninggal dunia menuntut upaya kolektif dalam bentuk apapun. Akademisi dapat ikut andil dengan melakukan studi sebagai upaya optimalisasi respons terhadap pandemi Covid-19, termasuk psikologi. Mengingat wabah memengaruhi mental masyarakat, riset-riset psikologi yang dapat menjadi basis intervensi psikologis untuk memperkuat mental masyarakat dalam upaya perlawanan terhadap Covid-19 juga diperlukan (Ho et al., 2020).

Covid-19 tidak hanya menyerang kondisi fisiologis manusia, melainkan juga kondisi psikologis. Beberapa riset mengonfirmasi dampak psikologis Covid-19, seperti kecemasan dan ketakutan (Huang et al., 2020), trauma vicarious (Z. Li et al., 2020), emosi negatif seperti depresi dan kemarahan (S. Li et al., 2020), kesehatan mental secara umum (Wang et al., 2020), dan bahkan gangguan stres pascatrauma (Sun et al., 2020; Zhang et al., 2020). Dampak psikologis tersebut tidak hanya dialami oleh pihak-pihak yang terlibat langsung seperti tim medis, melainkan juga masyarakat umum yang justru dilaporkan memiliki tingkat trauma vicarious lebih tinggi daripada tim medis di garda terdepan (Z. Li et al., 2020). Determinan lain yang juga dapat dipertimbangkan ialah jenis kelamin dan daerah tempat tinggal. Wanita dan masyarakat di perkotaan cenderung mengalami dampak psikologis berupa kecemasan dan ketakutan lebih tinggi; dibandingkan masyarakat desa yang cenderung mengalami kesedihan tinggi daripada perkotaan (Huang et al., 2020). Di samping jenis kelamin wanita, status siswa, gejala fisik spesifik seperti pusing, dan status kesehatan individual juga cenderung mengalami kecemasan, stres, dan depresi cukup tinggi (Wang et al., 2020).

Masyarakat Indonesia juga mulai mengalami dampak psikologis berupa kekhawatiran terhadap Covid-19 sehingga negara memerlukan kebijakan lockdown (Yunus \& Rezki, 2020), meskipun beberapa kalangan menunjukkan perilaku yang tidak mematuhi himbauan pemerintah oleh karena adanya bias kognitif (Buana, 2020). Misalnya potret berkumpul yang masih terjadi di beberapa tempat (misal: Azhari, 2020). Mengadakan perkumpulan semacam itu justru akan memperburuk ruang lingkup pandemi Covid-19 khususnya pada fase awal wabah (Ebrahim \& Memish, 2020). Hal ini mengindikasikan tidak adanya keselarasan antara upaya pemerintah dengan beberapa kalangan masyarakat yang diharapkan berperilaku adaptif. Dengan demikian maka diperlukan penelitian eksploratif tentang perilaku adaptif masyarakat terhadap wabah Covid-19.

Perilaku adaptif dapat muncul dari keyakinan yang optimis dan pengetahuan tentang Covid-19. Terkonfirmasi sebanyak 98\% dari masyarakat yang meyakini bahwa mereka mampu melawan Covid-19 menunjukkan perilaku adaptif berupa mengenakan masker saat bepergian (Zhong et al., 2020). Di Indonesia, ajakan untuk berperilaku adaptif 
berupa berdiam di rumah dilakukan oleh berbagai kalangan melalui media sosial dengan hashtag \#dirumahsaja. Perilaku ini tidak lain merupakan manifestasi dari kesadaran masyarakat untuk bergotong-royong dalam melawan Covid-19. Mendesaknya peningkatan angka masyarakat yang berdiam di rumah (\#dirumahsaja) daripada keluar rumah (\#tidakdirumah) sebagai tindakan kolektif melawan Covid-19 memerlukan identifikasi ilmiah yang memberi kalkulasi bobot dari faktor-faktor potensial, sehingga dapat menjadi referensi para pemangku kebijakan.

\section{Metode}

Penelitian ini melibatkan 272 responden yang terdiri dari 88 pria dan 184 wanita dengan rata-rata usia 24,4 tahun ( $\mathrm{SD}_{\text {usia }}=10,38$ ). Atas pertimbangan lebarnya interval usia responden, maka usia responden dikategorikan ke dalam tiga kategori perkembangan: remaja, dewasa awal, dan dewasa madya. Pengumpulan data dilakukan pada tanggal 30 Maret sampai 04 April 2020, yang diadministrasikan dan diisi oleh responden secara online melalui Google Form. Ketika pengisian kuesioner berlangsung, responden berada di sejumlah daerah Indonesia di antaranya Yogyakarta (80 responden), Jateng (73), Jabar (42), Bengkulu (12), Jatim (11), Sumut (9), Kaltim (7), Banten (7), Kalbar (5), Jambi (5), Kep. Bangka Belitung (4), Kalsel (4), Kep. Riau (3), Sumsel (2), Sulteng (2), Lampung (2), Jakarta (2), dan Bali (1). Data eksplorasi diperoleh dengan menggunakan tiga pertanyaan terbuka: ${ }^{1}$ Menurut Anda, siapa yang bertanggung jawab atas wabah COVID-19? ${ }^{2}$ Bagaimana perasaan Anda dalam menyikapi penyebaran wabah COVID-19? 'Bagaimana Anda melakukan pencegahan COVID-19? Dengan meminjam kerangka kerja pendekatan grounded theory, data kualitatif ini kemudian dianalisis dengan teknik content analysis (Faturochman et al., 2017).

Data kecenderungan \#dirumahsaja diperoleh dari transformasi data tentang waktu keberadaan di rumah dalam sehari (jam). Pertanyaan ini memberikan empat opsi jawaban, yaitu (a) 1 - 6 jam, (b) 7 - 12 jam, (c) 13 - 18 jam, dan (d) 19 - 24 jam. Jawaban (a) dan (b) dikategorikan sebagai kecenderungan \#tidakdirumah; sebaliknya, jawaban (c) dan (d) dikategorikan sebagai kecenderungan \#dirumahsaja. Data transformasi kecenderungan \#dirumahsaja akan diprediksi oleh jenis kelamin (pria dan wanita), fase perkembangan (remaja, dewasa awal, dan dewasa madya), dan ketiga domain psikologis hasil analisis eksploratif. Seluruh data nominal tersebut digunakan untuk memprediksi kecenderungan antara \#dirumahsaja dan \#tidakdirumah yang dikonstruksi menggunakan machine learning model decision tree dengan konfigurasi $80 \%$ data untuk pelatihan (testing) dan $20 \%$ data untuk pengujian (testing) dengan menggunakan perangkat lunak KNIME. 


\section{Hasil}

Content analysis dilakukan terhadap jawaban deskriptif dari ketiga pertanyaan terbuka. Berdasarkan hasil olah data pertama (open coding), ditemukan 31 kata kunci untuk pertanyaan tentang perilaku adaptif terhadap COVID-19. Pada proses axial coding, diperoleh 9 subtema untuk skema kognitif, 14 subtema untuk skema afektif, dan 10 subtema untuk skema perilaku. Pada tahap selective coding, hasil axial coding tersebut dikategorikan berdasarkan kesamaan makna ke dalam tiga tema utama untuk masingmasing skema psikologis. Tabel 1 menyajikan persentase tema-tema utama skema kognisi, afeksi, dan perilaku.

Berdasarkan Tabel 1, pihak yang paling bertanggung jawab atas wabah COVID-19 ialah diri sendiri $(67,65 \%)$, yang merepresentasikan masyarakat Indonesia dan umat manusia seluruhnya. Hal ini mengindikasikan bahwa COVID-19 dapat dicegah dan dihentikan oleh masyarakat dengan cara bergotong-royong atau kooperasi; bukan dibebankan kepada pihak tertentu, seperti negara asal virus (4,04\%). Ditinjau dari skema afektif, tidak ada bentuk perasaan yang mendominasi secara signifikan, melainkan relatif merata. Artinya, perasaan cemas $(47,79 \%)$ mengungguli upaya untuk tetap tenang dan sedih dalam skala yang relatif kecil. Namun demikian, berdasarkan komparasi subtema, upaya tetap tenang $(19,49 \%)$ menjadi subtema afektif paling dominan di antara subtema lainnya, seperti perasaan takut, cemas, dan sedih. Adapun perilaku adaptif terhadap wabah COVID-19 lebih ditunjukkan dalam bentuk memutus rantai penyebaran virus $(45,22 \%)$ dan menjaga pola hidup bersih dan sehat $(42,28 \%)$ daripada sebatas mengikuti anjuran pemerintah (12,5\%). Hal ini mengindikasikan bahwa perilaku adaptif lebih dipandang sebagai respons alamiah terhadap ancaman (COVID-19) yang didasari kesadaran individual, daripada dipandang sebagai wujud kepatuhan

Tabel 1.

Hasil Kategorisasi Tema

\begin{tabular}{|c|c|c|c|c|}
\hline & Tema & Subtema & Jumlah & Persentase \\
\hline \multirow{9}{*}{$\begin{array}{l}\text { Tanggung jawab } \\
\text { atas wabah } \\
\text { COVID-19 }\end{array}$} & \multirow{4}{*}{ Diri sendiri } & $\begin{array}{l}\text { Masyarakat } \\
\text { bersama }\end{array}$ & 89 & $32,72 \%$ \\
\hline & & Diri sendiri & 84 & $30,88 \%$ \\
\hline & & Manusia & 11 & $4,04 \%$ \\
\hline & & Total & 184 & $67,65 \%$ \\
\hline & \multirow{3}{*}{$\begin{array}{l}\text { Pemangku } \\
\text { kebijakan }\end{array}$} & Pemerintah & 58 & $21,32 \%$ \\
\hline & & Tenaga medis & 4 & $1,47 \%$ \\
\hline & & Total & 62 & $22,79 \%$ \\
\hline & & Negara asal virus & 11 & $4,04 \%$ \\
\hline & Objek lain & $\begin{array}{l}\text { Orang yang keluar } \\
\text { rumah untuk } \\
\text { urusan yang tidak } \\
\text { perlu }\end{array}$ & 6 & $2,21 \%$ \\
\hline
\end{tabular}




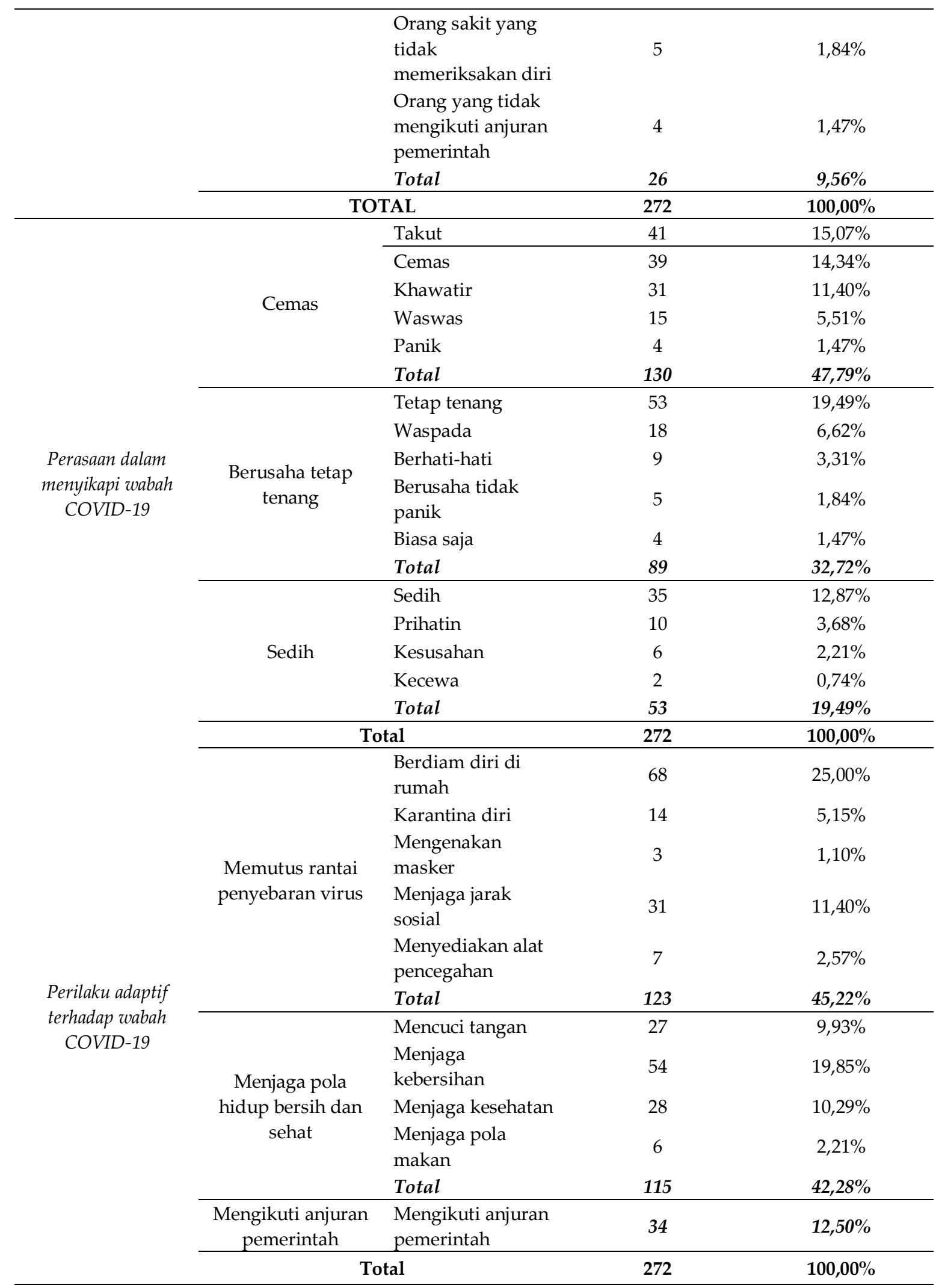

Tahap prediksi dilakukan dengan menggunakan machine learning model decision tree. Model ini digunakan untuk memprediksi kecenderungan \#dirumahsaja atau \#tidakdirumah berdasarkan jenis kelamin (pria; wanita), fase perkembangan (remaja; 
dewasa awal; dewasa madya), pihak yang bertanggung jawab atas Covid-19 (diri sendiri; pemangku kebijakan; objek lain), perasaan dalam menyikapi Covid-19 (cemas; berusaha tetap tenang; sedih), dan perilaku adaptif terhadap wabah Covid-19 (memutus rantai penyebaran virus; menjaga pola hidup bersih dan sehat; mengikuti anjuran pemerintah).

Berdasarkan model decision tree (Gambar 1, hal. 142), jenis kelamin menjadi prediktor terbaik dalam menentukan kecenderungan \#dirumahsaja, yang secara spesifik wanita memiliki kecenderungan \#dirumahsaja (80,7\%) daripada pria yang cenderung \#tidakdirumah (51,4\%). Pada pria, prediktor terbaik berikutnya ialah pihak yang bertanggung jawab atas Covid-19. Pada wanita, prediktor terbaik berikutnya ialah bentuk perilaku adaptif terhadap Covid-19. Ditinjau dari tingkat akurasinya (100\%), kecenderungan \#tidakdirumah terjadi pada kategori pria dewasa madya yang berpikir bahwa Covid-19 merupakan tanggung jawab pemangku kebijakan; sementara kecenderungan \#dirumahsaja terjadi pada kategori wanita dewasa awal dan dewasa madya yang merasa cemas akan Covid-19 dan berperilaku adaptif dengan memutus rantai penyebaran virus.

\section{Gambar 2.}

Grafik Uji Model

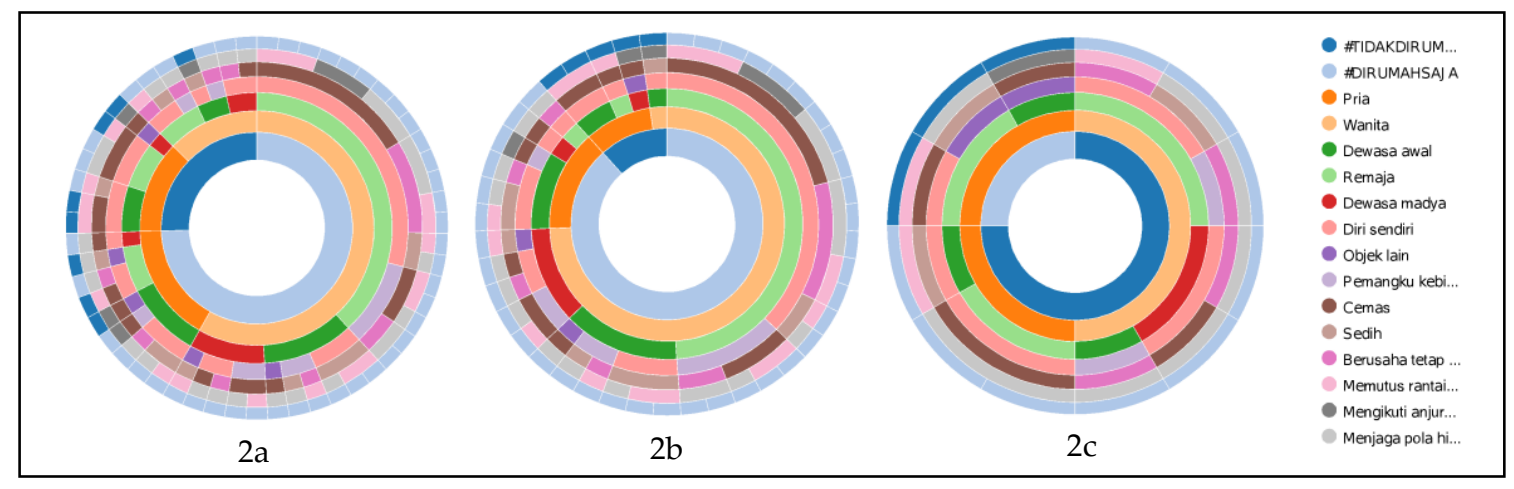

Gambar 2a menunjukkan grafik sunburst hasil pengujian terhadap model decision tree. Model dapat memprediksi kecenderungan \#dirumahsaja dengan tingkat akurasi sebesar 78,182\% dengan koefisien Cohen's Kappa ( $\kappa$ ) sebesar 0,331 (fair strength of agreement). Grafik menunjukkan 43 ketepatan klasifikasi (78,182\%) dan 12 kesalahan klasifikasi (21,818\%) dari kecenderungan \#dirumahsaja antara data observasi (biru lapisan terdalam) dengan data prediksi (biru lapisan terluar). Ketepatan prediksi (Grafik 2b) didominasi oleh kecenderungan \#dirumahsaja dengan rasio perbandingan 7,6:1 terhadap kecenderungan \#tidakdirumah. Adapun kesalahan prediksi (Grafik 2c) didominasi oleh kecenderungan \#tidakdirumah dengan rasio perbandingan 3:1 terhadap kecenderungan \#dirumahsaja. 


\section{Diskusi}

Pemikiran bahwa Covid-19 merupakan tanggung jawab bersama menjadi modal kognitif dalam memunculkan perilaku adaptif. Pemikiran ini dapat dilatarbelakangi oleh perasaan bersalah kolektif pada sekelompok besar masyarakat, sehingga meyakini penanganan terhadap COVID-19 tidak dapat dibebankan pada pihak-pihak tertentu saja, melainkan memerlukan tindakan gotong-royong atau kooperatif. Secara teoretis, perasaan bersalah mendorong individu untuk berperilaku kooperatif bahkan pada kondisi dilema sosial (Mesquita et al., 2012). Potret dilema sosial sebagai dampak dari Covid-19 dapat dilihat, misalnya, dari perilaku menimbun makanan. Pada contoh ini, individu dihadapkan pada situasi interdependen, yang jika berfokus pada kepentingan personal maka akan merugikan secara sosial; dan sebaliknya, jika tidak berfokus pada kepentingan personal maka berpotensi dirugikan oleh pihak lain.

Berdasarkan teori aksi kolektif, perlu untuk menggeser hasil ekuilibrium Nash yang tidak efisien tetapi stabil ke arah pareto-superior yang saling menguntungkan (Holahan \& Lubell, 2016). Artinya, ketika individu memilih perilaku non-kooperatif dalam mencegah Covid-19 untuk melindungi dirinya sendiri dengan mempertimbangkan perilaku orang lain (misal: orang lain juga menimbun makanan), maka situasi semacam ini perlu diarahkan pada situasi yang tidak berisiko mengurangi kesejahteraan tertinggi individu lain. Dengan demikian, keyakinan bahwa Covid-19 merupakan tanggung jawab bersama dapat menjadi kontrol atas perilaku non-kooperatif seperti menimbun makanan. Zhong et al. (2020) juga menjelaskan bahwa keyakinan optimisme masyarakat Cina mendorong perilaku proaktif berupa pemakaian masker.

Bobot konsekuensi perasaan masyarakat terhadap perilaku dalam menyikapi wabah Covid-19 juga perlu dieksplorasi. Penelitian ini mengonfirmasi bahwa angka kecemasan melampaui upaya untuk tetap tenang. Kondisi ini perlu diwaspadai agar kecemasan pada masyarakat tidak terus meningkat karena berisiko pada perilaku nonkooperatif atau bahkan maladaptif, seperti diberitakan peningkatan kasus KDRT di dunia akibat Covid-19 (misal: Rizal, 2020). Berdasarkan feelings-as-information theory, Schwarz (2012) menjelaskan bagaimana perasaan dapat menjadi basis dari pengambilan keputusan layaknya informasi. Ketika pengetahuan tentang suatu informasi rendah, maka perasaan menjadi sumber tunggal yang mendasari perilaku. Zhong et al. (2020) juga mengonfirmasi bahwa pengetahuan tentang Covid-19 dapat membentuk keyakinan optimis masyarakat dalam melawan Covid-19. Dengan demikian, maka upaya menjaga masyarakat agar tetap tenang saja tidak cukup untuk menekan angka kecemasan, melainkan juga perlu dibarengi dengan peningkatan pengetahuan tentang Covid-19 sehingga membentuk mental optimisme yang berpotensi memunculkan perilaku adaptif. 
Perilaku adaptif yang pada penelitian ini mayoritas dimanifestasikan dengan memutus rantai penyebaran virus dan menjaga pola hidup bersih dan sehat dapat dilatarbelakangi oleh kecemasan atau ketakutan terhadap virus yang sangat berisiko mematikan ini. Berdasarkan terror management health model (TMHM) pengembangan terror management theory (TMT), Greenberg dan Arndt (2012) menjelaskan secara gamblang bagaimana individu mengambil langkah proaktif atau langkah menghindari untuk mengurangi kecemasan akan kematian. Ketika pemikiran eksplisit mengenai kematian muncul, individu bereaksi dengan mencoba menghindari ancaman atau mengurangi kecemasannya dengan perilaku meningkatkan kesehatan. Artinya pada konteks Covid19, perasaan kecemasan dapat menjadi dorongan kolektif yang memunculkan perilaku proaktif (misal: mengenakan masker, mencuci tangan, menjaga jarak sosial) atau perilaku pencegahan seperti berdiam di rumah (\#dirumahsaja).

Pada penelitian ini, kecenderungan \#dirumahsaja ditunjukkan oleh wanita dewasa awal dan madya yang merasa cemas akan Covid-19 dan berperilaku adaptif dengan memutus rantai penyebaran virus. Hal ini sejalan dengan penelitian Wang et al. (2020), bahwa mayoritas responden penelitiannya memilih untuk diam di rumah dan merasa cemas jika ada keluarganya terkena Covid-19. Secara spesifik, dalam penelitian tersebut, responden berjenis kelamin wanita mengalami kecemasan lebih tinggi. Huang et al. (2020) juga mengonfirmasi bahwa kecemasan dan ketakutan ini lebih tinggi dialami oleh masyarakat perkotaan dan wanita. Hal ini mengindikasikan bahwa keberadaan geografis tempat tinggal dan jenis kelamin berpotensi memprediksi perilaku adaptif seperti berdiam di rumah (\#dirumahsaja). Demikian halnya model prediksi penelitian ini, kecenderungan \#dirumahsaja lebih akurat diprediksi oleh kategori jenis kelamin wanita daripada pria yang cenderung \#tidakdirumah.

\section{Kesimpulan}

Penelitian menemukan bahwa penyebaran Covid-19 menjadi tanggung jawab bersama, yaitu masyarakat Indonesia dan umat manusia seluruhnya, yang berpotensi dicegah dan dihentikan dengan cara gotong royong. Meskipun secara umum wabah Covid-19 menimbulkan perasaan cemas, namun jika ditinjau lebih spesifik lagi ditemukan justru upaya tetap tenang mendominasi perasaan spesifik lainnya, seperti perasaan takut, cemas, ataupun sedih. Perilaku adaptif terhadap wabah Covid-19 secara umum didorong kesadaran individual dalam bentuk memutus rantai penyebaran virus dan menjaga pola hidup bersih dan sehat daripada didorong atas dasar kepatuhan terhadap pemerintah. Adapun ditinjau dari model decision tree, jenis kelamin menjadi prediktor terbaik dalam menentukan kecenderungan \#dirumahsaja. Ditinjau dari tingkat akurasinya, pria dewasa madya meyakini bahwa pemangku kebijakan sebagai pihak yang bertanggung jawab atas wabah cenderung \#tidakdirumah; sementara wanita dewasa awal dan dewasa madya 
yang merasa cemas akan Covid-19 dan berperilaku adaptif dengan memutus rantai penyebaran virus cenderung \#dirumahsaja.

\section{Saran}

Penelitian ini memiliki implikasi yang penting dalam upaya membangun perilaku kooperatif untuk melawan wabah Covid-19. Pada tataran kognitif, masyarakat menilai bahwa wabah ini menjadi tanggung jawab bersama dan bukan dibebankan pada pihak tertentu. Keyakinan kolektif ini diharapkan akan memunculkan dan menguatkan perilaku kolektif untuk bergotong-royong melawan Covid-19. Pada tataran afektif, masyarakat cukup mampu mengontrol dan mengendalikan emosi diri untuk tetap tenang. Perasaan tenang perlu terus dikedepankan untuk menekan perasaan cemas, sehingga dapat mendorong munculnya perilaku kooperatif. Optimisme melawan Covid19 juga ditunjukkan dengan perilaku adaptif masyarakat yang menunjukkan perilaku kolektif didasarkan pada kesadaran dan kepedulian dalam bentuk upaya pemutusan rantai penyebaran virus dan menjaga pola hidup bersih dan sehat.

\section{Ucapan terima kasih}

Penulis mengucapkan terima kasih kepada mahasiswa psikologi Universitas Teknologi Yogyakarta yang telah bersedia menjadi partisipan penelitian ini.

\section{Kontribusi penulis}

Penulis melakukan keseluruhan penelitian dari studi literatur, pengambilan data, pengolahan data, analisis data, pelaporan hasil, hingga publikasi.

\section{Konflik kepentingan}

Penulis tidak memiliki konflik kepentingan dalam pelaksanaan, penyusunan, dan publikasi penelitian ini. Pelaksanaan penelitian dilakukan di masa awal pandemi atas rasa penasaran penulis pribadi.

\section{Pendanaan}

Penelitian ditanggung dana personal penulis.

\section{orCid ID}

Tabah Aris Nurjaman 0000-0002-6206-7070

\section{Kepustakaan}

Azhari, J. R. (2020, 05 April). 18 Orang ditangkap karena berkerumun saat ada wabah Covid-19. Kompas. Diakses dari https://megapolitan.kompas.com

Buana, D. (2020). Analisis perilaku masyarakat Indonesia dalam menghadapi pandemi virus corona (Covid-19) dan kiat menjaga kesejahteraan jiwa. SALAM Jurnal Sosial \& Budaya Syar-I, 7(3), 217-226. https://doi.org/10.1017/CBO9781107415324.004

Gugus Tugas Percepatan Penanganan COVID-19. (2020, 11 April). Data sebaran COVID-19. 
Diakses dari https://covid19.co.id

Ebrahim, S. H., \& Memish, Z. A. (2020). COVID-19: The role of mass gatherings. Travel Medicine and Infectious Disease, March, 101617. https://doi.org/10.1016/j.tmaid.2020.101617

Faturochman, Minza, W. M., \& Nurjaman, T. A. (2017). Memahami dan mengambangkan indigenous psychology. Pustaka Pelajar.

Greenberg, J., \& Arndt, J. (2012). Terror management theory. Dalam P. Van Lange, A. Kruglanski, \& E. Higgins (Eds.), Theories of social psychology (Vol. 1, hal. 398-415). London: SAGE Publications.

Ho, C. S., Chee, C. Y., \& Ho, R. C. (2020). Mental health strategies to combat the psychological impact of COVID-19 beyond paranoia and panic. Annals of the Academy of Medicine, Singapore, 49(1), 1-3.

Holahan, R., \& Lubell, M. (2016). Collective action theory. Dalam C. Ansell \& J. Torfing (Eds.), Handbook on theories of governance (hal. 21-31). https://doi.org/10.4337/9781782548508.00010

Huang, L., Xu, F. M., \& Liu, H. R. (2020). Emotional responses and coping strategies of nurses and nursing college students during COVID-19 outbreak. https://doi.org/10.1101/2020.03.05.20031898

Li, S., Wang, Y., Xue, J., Zhao, N., \& Zhu, T. (2020). The impact of covid-19 epidemic declaration on psychological consequences: A study on active weibo users. International Journal of Environmental Research and Public Health, 17(6). https://doi.org/10.3390/ijerph17062032

Li, Z., Ge, J., Yang, M., Feng, J., Qiao, M., Jiang, R., Bi, J., Zhan, G., Xu, X., Wang, L., Zhou, Q., Zhou, C., Pan, Y., Liu, S., Zhang, H., Yang, J., Zhu, B., Hu, Y., Hashimoto, K., ... Yang, C. (2020). Vicarious traumatization in the general public, members, and nonmembers of medical teams aiding in COVID-19 control. Brain, Behavior, and Immunity, March, 0-1. https://doi.org/10.1016/j.bbi.2020.03.007

Mesquita, B., Marinetti, C., \& Delvaux, E. (2012). The social psychology of emotion. Dalam S. T. Fiske \& C. N. Macrae (Eds.), The SAGE handbook of social cognition (hal. 291310). London: SAGE Publications.

Rizal, J. G. (2020, 06 April). Dampak virus corona: Kasus KDRT di dunia meningkat akibat COVID-19. Kompas. Diakses dari https://kompas.com

Schwarz, N. (2012). Feelings-as-information theory. Dalam P. Van Lange, A. Kruglanski, \& E. Higgins (Eds.), Theories of social psychology (Vol. 1, hal. 289-308). London: SAGE Publications.

Sun, L., Sun, Z., Wu, L., Zhu, Z., Zhang, F., Shang, Z., Jia, Y., Gu, J., Zhou, Y., Wang, Y., Liu, N., \& Liu, W. (2020). Prevalence and risk factors of acute posttraumatic stress symptoms during the COVID-19 outbreak in Wuhan, China. https://doi.org/10.1101/2020.03.06.20032425

Wang, C., Pan, R., Wan, X., Tan, Y., Xu, L., Ho, C. S., \& Ho, R. C. (2020). Immediate psychological responses and associated factors during the initial stage of the 2019 coronavirus disease (COVID-19) epidemic among the general population in China. International Journal of Environmental Research and Public Health, 17(5). https://doi.org/10.3390/ijerph17051729

Yunus, N., \& Rezki, A. (2020). Kebijakan pemberlakuan lockdown sebagai antisipasi penyebaran corona virus Covid-19. SALAM Jurnal Sosial \& Budaya Syar-I, 7(3), 227- 
237. https://doi.org/10.1017/CBO9781107415324.004

Zhang, F., Shang, Z., Ma, H., Jia, Y., Sun, L., Guo, X., Wu, L., Sun, Z., Zhou, Y., Wang, Y., Liu, N., \& Liu, W. (2020). High risk of infection caused Posttraumatic Stress symptoms in individuals with poor sleep quality: A study on influence of Coronavirus disease (COVID-19) in China. https://doi.org/https://doi.org/10.1101/2020.03.22.20034504

Zhong, B.-L., Luo, W., Li, H.-M., Zhang, Q.-Q., Liu, X.-G., Li, W.-T., \& Li, Y. (2020). Knowledge, attitudes, and practices towards COVID-19 among Chinese residents during the rapid rise period of the COVID-19 outbreak: a quick online crosssectional survey. International Journal of Biological Sciences, 16(10), 1745-1752. https://doi.org/10.7150/ijbs.45221 


\section{Gambar 1.}

Decision Tree Model

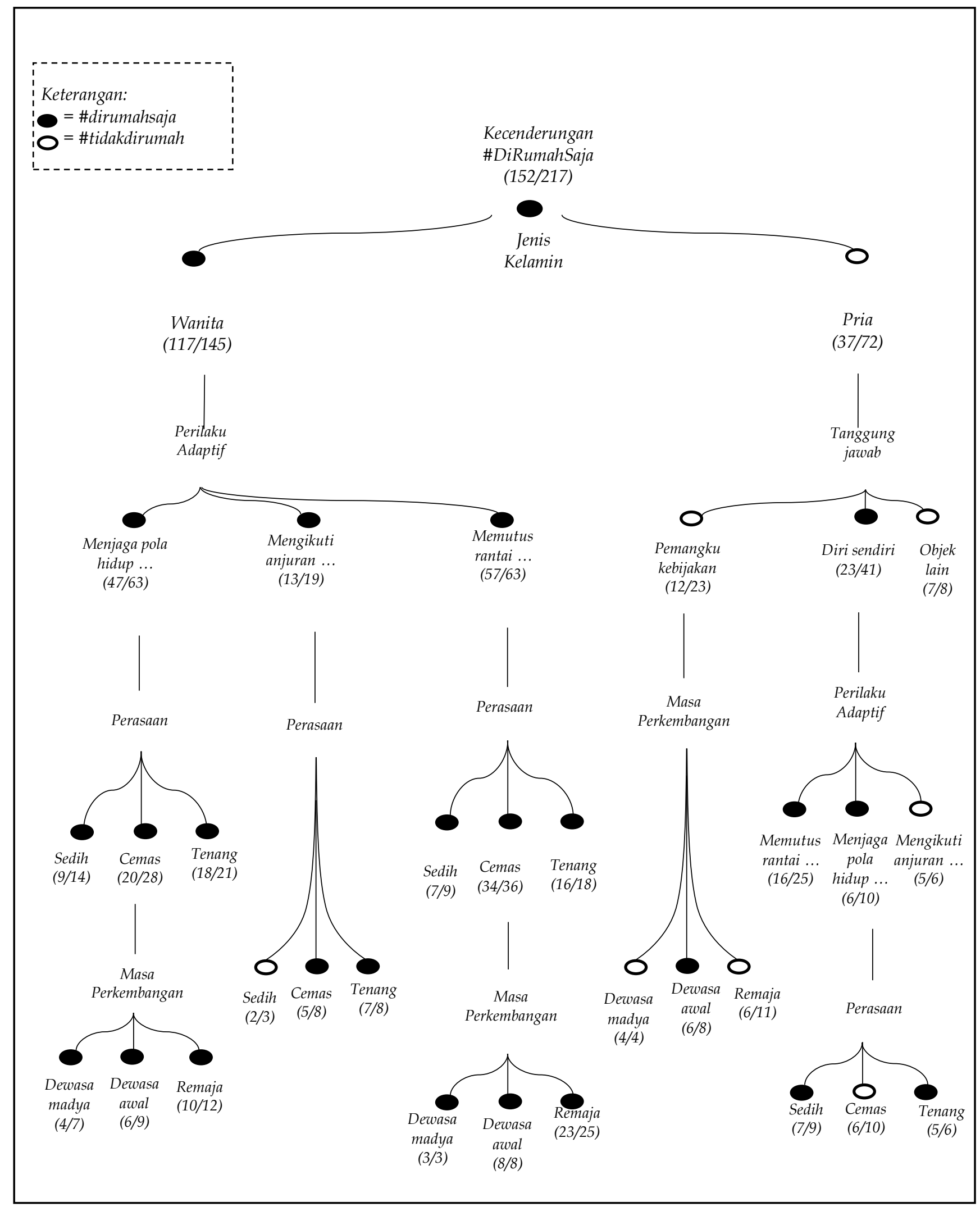

